\title{
Kungälv '71: A Retrospect
}

By E. Kielland-Lund, University of Oslo

The fourth Conference of the Nordic Association for American Studies convened at Kungälv near Gothenburg, Sweden, on the 23rd of June for four busy and rewarding days of intellectual and social stimulus. The planning of the Conference, originally scheduled for 1970 but postponed a year because of unforeseen difficulties, had been in the hands of the Danish chapter of the N.A.A.S., with Professor Eric Jacobsen as chairman. The choice of Nordens Folkliga Akademi at Kungälv as the site of the Conference seemed thoroughly felicitous, providing the participants with excellent facilities for academic, social, and personal needs. With a geographical location worthy of a seperate panegyric (on a rocky hill overlooking the Gotha River and Bohus Castle) and a list of speakers equally notable for uniformity of excellence and diversity of subject matter, it became clear from the start that the Danish hosts had managed to provide the raw materials for a truly memorable Conference. The active response of the individual members of the N.A.A.S. further ensured the success of the Conference, the general subject of which was 'The U.S.A. in the 70's: Roles and Realities."

Because of the limited capacity of the Kungälv Academy (combined with some overlapping with another conference the first day), the number of participants had to be cut down to approximately 55. The bulk of the Kungälv assembly was fairly evenly divided between Denmark, Finland, Norway, and Sweden, with representatives from Iceland and American scholars in Europe completing the picture.

The lecture program seemed designed to furnish a broad view of current "roles and realities" afflicting and challenging presentday American society. Professor K. E. Svendsen of Copenhagen, political economist and personal adviser to President Nyerere of 
Tanzania, opened the lecture series with a talk on "The U.S.A. and the Third World." During the marathon question-and-answer. session that followed the lecture, the audience made it abundantly clear that it appreciated the opportunity of having their questions answered by an authority with first-hand knowledge of the multifarious problems facing an underdeveloped country in the 1970's. Professor Peter I. Rose of Smith College, Mass., in two lectures entitled "The U.S.A. and the problems of Race," provided his audience with both a historical perspective on the development of the "Negro Movement" in the U.S. and a comprehensive survey of the ramifications of the racial problems encountered on the contemporary American scene. In the final lecture, entitled "U.S. Literature: America and its Discontents," Professor Larzer Ziff of Berkeley took his audience on a spirited and sprightly tour of the contemporary literary landscape in America. Quoting extensively from writers like Lowell, Mailer, Brautigan, and others, Professor Ziff evoked the spririt of a disillusioned post-technological literature on the move from Reason towards Intuition, from the confines of rational, scientific thought towards the free-floating irrationality of "Mind at Large."

After each lecture, the assembly divided into six permanent subgroups for further discussion of lecture topics, and for the formulation of additional questions for the lecturers to answer in a final session. Thus, each individual was given a chance to play a more active role in the proceedings. On the whole the system of alternating lectures/group discussions seemed to work quite effectively, as proved by the reduction of actual group discussion time to about half of what had been proposed in the original schedule.

On the 25th of June the General Assembly of the N.A.A.S. met, and proceeded to elect Harald Elovson as its chairman. In the dicussion of the present situation of the Association, general satisfaction was expressed regarding the new dispensation according to which the American Council of Learned Societies replaces the U.S. government as the most important non-Scandinavian source of financial support for the Association and its conferences. For the future, it was felt that it would be wise to keep the present general and relatively "popular" scope of the N.A.A.S. Conference.
But to meet the demands of those members who felt that a greater degree of specialization is desirable, it was suggested that one could add a day or two to the general conference for those interested in discussions on a more scholarly level. To further enlarge the scope of the Association's activities, it was proposed that specialized symposia or panels be arranged between conferences, largely on a national basis, but with invited specialists from other countries as well. The possibility of a conference on the general problem of Area Studies, paid for by the universities, was also suggested.

Generally, the Assembly felt skeptical about the creation of separate National Committees within the N.A.A.S. It was decided, however, that one participating Board Deputy (substitute, "suppleant") and one member of a Newsletter Editorial Committee be elected from each country. If need be, the ordinary Board Member, the Board Deputy, and the Member of the Editorial Committee could serve as an ad boc National Committee.

At the elections a strong desire for a rejuvenation of the Executive Board was expressed by its present members. Professor Sigmund Skard, who had been serving as Acting Chairman of the Association since Professor Åhnebrink's death in 1967, was elected Chairman, but only until the next Conference. The other Board Members were re-elected: Dr. Sune Åkerman (Secretary-Treasurer and Member from Sweden), Professor Ian Kirby (until he leaves Iceland in 1972, then to be succeeded by Dr. Jóhann S. Hannesson, Reykjavík), Professor Eric Jacobsen (Denmark), and Professor Ole Reuter (Finland). The Members from Denmark and Finland accepted re-election with the provision that younger substitutes for them be found as soon as possible. As Norwegian Deputy to the Board was elected Dosent Brita Seyersted, while Dosent Orm Øverland was elected Norwegian Member of the Editorial Committee. For the other countries, election to these offices was postponed and the Board authorized to approve subsequent nominees.

It was decided to hold the next N.A.A.S. Conference in 1973, to make up for the year lost in the planning of the present Conference. The planning of the '73 Conference was entrusted to the Swedish members of the Association, and the present Kungälv location was deemed so satisfactory as to deserve an encore in two year's time. 
No account of this year's Conference would be complete without a few words about the "extracurricular activities" that provided the participants with the happy balance of work and play that made the four days at Kungälv such an enriching experience. The Midsummer Night celebration in the country (complete with maypoles, fiddlers, and folk dancers) and the boat trip to Marstrand were thoroughly enjoyable breaks in the Conference routine. Furthermore, the daily work schedule was never so crowded that it did not give a decent opportunity for the informal exchange of views on all and sundry topics that characterized the many groups that dotted the Conference landscape. Although a certain clannishness was observable among the national groups, the connections made and the fellowship enjoyed may well prove to be the single most important aspect of a conference of this kind. Certainly it made the reality of the N.A.A.S. much more palpable for this member, and I have a distinct feeling that this was a reaction shared by rookies and veterans alike.

Finally, a word of thanks to Lektor Ove Elvekjær and his staff at the Academy, who contributed in large measure towards the smooth operation and pleasant atmosphere that characterized the Conference. To them and to the members of the N.A.A.S. it but remains to say: "See you soon in '73!"' 